UDC: 658

JEL Classification: M11, M12

doi: 10.31767/nasoa.1-2-2021.04

LI QINGSEN,

Master,

Faculty of Management and Marketing, e-mail: li.qingsen21@gmail.com, ORCID: 0000-0002-5871-4757,

L. ARTEMENKO,

PhD in Economics, Associate Professor, Department of Business Management; National Technical University of Ukraine "Igor Sikorsky Kyiv Polytechnic Institute,

\title{
Aproaches to Forming the Company's Strategic Goals
}

Defining the general direction of the organization, namely the vision, mission and its corporate values, is the primary goal of forming strategic goals. Vision of the future of the company is becoming an increasingly important element. Management can develop several alternative strategic scenarios and evaluate them in terms of the organization's long-term goals. To begin implementing the chosen strategy (or to continue re-validation), management specifies it in terms of actions to be taken in the near future.

The article considers the concept of "strategy", the process of developing a strategy for the company, the importance of the mission and goals for the development of the company, as well as the requirements, compliance with which allows one to develop an optimal strategy for the organization. The model of a choice of the company's strategic orientation is propose. The steps that allow companies to develop a strategic process are identified.

Keywords: strategy, company development strategy, functional strategies, competitive advantages, marketing strategy, benchmarking.

ЛІ ЦІНСЕНЬ,

магістр,

факультет менеджменту і маркетингу;

Л. П. АРТЕМЕНКО,

кандидат економічних наук, дочент, кафедра менеджменту підприємств; Наиіональний технічний університет Украйни "Київський політехнічний інститут імені Ігоря Сікорського"

\section{Підходи до формування стратегічних цілей компанії}

Визначення загального напряму діяльності організачії, а саме ї̈ бачення, місії та корпоративних изінностей є першорядною метою формування стратегічних изілей. Бачення майбутнього компанії стає дедалі важливішим елементом. Керівництво може скласти кілька альтернативних стратегічних сценаріїв та оцінити їх з погляду довгострокових иілей організачії. Щоб розпочати реалізацію обраної стратегії (або продовжити повторну валідацію), керівництво конкретизує ї̈ з погляду дій, які необхідно здійснити в найближчому майбутньому.

У статті розглянуто поняття “стратегія”, прочес розроблення стратегії для компанії, значущість місії та изілі для ії розвитку, а також вимоги, дотримання яких дозволяє розробити оптимальну стратегію для розвитку організаиії. Запропоновано модель вибору стратегічної орієнтації компанії. Визначено кроки, які дозволяють

(C) Li Qingsen, L. Artemenko, 2021 
компаніям розробити стратегічний процес.

Ключові слова: стратегія, стратегія розвитку компанії, функціональні стратегії, конкурентні переваги, стратегія маркетингу, бенчмаркетинг.

Introduction. Through the prism of strategy, various business situations that the organization faces in everyday life are analyzed. The ability of the company to apply an independent strategy in all areas increases the competitive status of the enterprise, makes it more flexible, stable, and allows it to adequately respond to the requirements of the time and market conditions. The strategy is formed taking into account the analysis of the impact of the internal and external environment, which determines the need for its constant development and timely response to market requirements.

The purpose of the article is to consider the concept of "strategy", the process of developing a strategy for the enterprise, the significance of the mission and goals for the development of the company, as well as the requirements that allow you to develop an optimal strategy for the development of the organization. A model for choosing the strategic orientation of the enterprise is proposed.

Literature review. Theoretical, practical and methodological aspects of the formation and implementation of enterprise strategies were considered in the works of such domestic and foreign scientists as Z. Shershneva, I. Ansoff, M. Mescon, A. Vikhansky, S. Popov, G. Mintsberg, A. Chandler, G. Azoev, I. Ansoff, A. Arefyeva, A. Vikhansky, A. Voronkova, I. Gerchikova, V. Gorelova, A. Gradov, V. Dikan, M. Ermoshenko, P. Zavyalov, Yu. Ivanov, F. Kotler, A. Naumov, O. Peshkova, V. Ponomarenko, M. Porter, O. Pushkar, Yu. Rubin, V. Starodubrovskaya, R. Tikhonov, R. Fatkhutdinov, O. Chernegi, A. Yudanov and others. However, the analysis of literature sources shows that there is no clear, specific sequence of actions for the formation and implementation of the strategy. But business practice shows that a successful strategy cannot be copied and there is no single strategic priority for all enterprises either. Therefore, the issue of formation and prerequisites for the implementation of enterprise strategies requires further research.

Research results. The strategy allows you to focus your efforts on the main areas and discard secondary ones; develop and coordinate actions to implement the mission and main goals of the company, ways to transform it into a new state (which business to stop, which to sell, in which to move, with which to merge), ways to use the resources necessary for this [5].

The development of the company's development strategy should be carried out taking into account the following requirements:

- Adequacy, which implies its compliance with the market situation, the company's goals, the technical and economic potential of the company, the experience and skills of employees and managers, the corporate culture, and the existing management system.

- Integrity, consistency of individual elements, logical sequence that generates a synergistic effect.

- Ethics ,morality (the implementation of the strategy should not cause actions that contradict the norms of morality and law).

- Compatibility with the environment, which makes it possible to interact with it (the strategy adapts to changes in the company's environment and can cause these changes itself).

- Justified riskiness.

- $\quad$ Focus on forming competitive advantages, increasing competitive status, and gaining success in the market.

- Taking into account the interests of society as a whole, as well as municipal authorities, business partners, personnel of the organization, the specifics of the industry and the position of the company in it.

- Alternativeness (as a rule, several variants of the strategy are developed, from which a specific direction of development of the organization is selected) [14].

The presence of a large number of factors that affect the development of the company, as well as the intensity of economic changes and the dynamism of markets, requires the company to have a long-term development strategy. The strategy, first of all, should influence the management behavior of the firm in the long term. With proper implementation of the strategy, the company has the ability to quickly and effectively respond to situations that occur when the external environment changes, introduce a new product and compete for a long time [2].

The company's strategy is a set of management and organizational approaches used to 
achieve long-term goals. The development of the company's strategy is based on general rules that are responsible for the procedure for achieving the company's long-term goals. In practice, these principles are transformed into the rules for evaluating the results of the company's performance at the current time and in the future:

- the qualitative aspect is a reference point, and quantitative content is a planned task;

- rules of conduct of the company with the external market, the process of product release and sale, methods for increasing superiority over competitors;

- rules for regulating processes and establishing relationships in the company;

- rules for the implementation of operational activities, systematize techniques and technologies for its implementation [12].

Economists distinguish several methods of successful development of a firm through strategy. According to M. Poter, the foundation of successful development of the company is leadership in reducing costs, a strategy of focusing and differentiation. It is worth considering other approaches: growth strategy, stability strategy, reduction strategy, level of corporate strategy, level of business strategies, level of functional strategies, reduction strategies, differentiated growth strategies, expansion and concentrated growth strategies [3].

As can be see, there are several types of enterprise development strategies and each of them is applied in practice depending on market factors, on the level of competitiveness, on the product life cycle, on the development opportunities of the enterprise, on the industry, as well as on management decisions. The company should set clear goals for itself and determine the priorities for completing its tasks, as well as provide it with the necessary resources and financial capabilities. Then it is necessary to convey the company's strategy plan to the personnel and determine under what conditions it is possible to use it. The highest level of the company needs to develop a management method that will take into account the intensity of changes in the market, as well as factors of leveling and eliminating risks [1].

The Soviet philosopher A. M. Popovych argues that in conditions of high competitiveness and instability in the market, all enterprise development strategies should be used in a complex, which will allow it to take into account all the factors that affect the formation of the strategy. The resource approach can provide an assessment of the company's available resources for making inputs to the business process, and stakeholder theory allows the company to evaluate its outputs in the course of its activities in the market or interested parties. Combining the resource approach and the theory of stakeholders can be implemented in such areas as: attracting current and main principles for the implementation of measures within the framework of corporate social responsibility, as well as identifying a single basis for the formation of key competencies and the ability to take into account the interests of stakeholders [10].

The strategy allows you to focus your efforts on the main areas and discard secondary ones; develop and coordinate actions to implement the mission and main goals of the company, ways to transform it into a new state (which business to stop, which to sell, in which to move, with which to merge), ways to use the necessary resources for this. The strategy is designed to provide the company with significant competitive advantages in those areas where there is the greatest chance of success; to help choose the types of products with which this can be achieved; to find ways to neutralize competitors. Through the implementation of the strategy, the company's strategic potential is formed as a set of material conditions for production activities, as well as professional and creative skills of personnel [8].

The essence of any business activity is the production of goods necessary for the consumer. From the interaction between the market and the product, the central problem of entrepreneurship is derived, on the solution of which the guarantee of the existence of the enterprise in this market depends. The marketing concept dictates the need to use strategic tools to solve the company's problems in the market. It is marketing mechanisms that allow you to achieve this as a result of analyzing information about the market, forming consumer commitment, and designing a competitive market position of the company.

Marketing strategy is the analysis of the company's capabilities in the market, the choice of a system of goals, the development and formulation of plans and implementation of marketing activities aimed at reducing market risk, ensuring long-term and sustainable development of the enterprise [6].

The marketing strategy allows you to create such conditions under which the company 
will avoid problems in the market. For this purpose, a wide arsenal of theoretical and practical marketing tools is used. The strategy affects the fate of the entire enterprise in the long term and is aimed at achieving strategic goals, implementing coordinated actions in the field of demand management. Based on this, the objectives of the marketing strategy are: business expansion, development of technological potential and production growth, creation of new products, development of new markets.

When developing a company's development strategy, it is necessary to take into account the following stages: opportunities and threats, the company's potential, endogenous and exogenous factors, the direction strategy, the main goals and missions of the company [7].

Any development of a company's strategy begins with strategic analysis, which includes the process of studying endogenous and exogenous factors. Everything generated by the external environment is classified as exogenous factors at the macro and micro levels. The macro environment includes such factors of influence as: natural and geographical, climatic, legal, general economic, socio-demographic, regional and technological. This group of factors is taken into account when the company needs to conduct a PEST analysis.

Elements of the microenvironment include: labor and material resources, the product sales market, resource suppliers, competitors, consumers, and capital. In order to analyze the microenvironment, you can use Porter's "Five Forces of Competition" model - existing and new competitors, the availability of substitute products and possible consequences from them, the company's relationships with suppliers, as well as the influence of customers. There are two more types of analysis of strategic groups: ADL - a method for assessing the industry life cycle, taking into account the company's competitive position; CFU - determining key success factors [4].

Endogenous factors include those factors of the enterprise that hinder its development. This can include: organizational culture, marketing, financial resources, production and personnel of the company. After the company has analyzed its endogenous and exogenous factors, which gives it the opportunity to find out the dependence of the internal and external environment, it needs to summarize its results in a SWOT analysis [11].

When conducting a SWOT analysis, the company should take into account the object of analysis, analyze its advantages and disadvantages in terms of the goal, identify possible threats and opportunities for it, identify criteria for launching a strategy in a particular situation, should make changes to the formulation of the strategy as the situation changes, take into account the time and financial framework when launching the strategy. In order for SWOT analysis to be the most accurate, the company needs to support it with quantitative indicators. Thanks to a well-designed SWOT analysis, an enterprise can count on a successful strategy that can increase not only financial performance, but also competitiveness in the sales market.

After the company has conducted a SWOT analysis, it needs to specify its actions on the development strategy, fix the goals set and, if necessary, make changes to them. The company's strategy should reflect the main directions for the development of the enterprise. When carrying out its activities, the company develops its own manner of behavior in the fight against competitors, discovers new production methods, participates in pricing and investment policy [10].

A successful development plan for any company should be relevant for a long period of time and should be able to adapt to the flexibility of the modern market. It is the plan that provides an understanding of the future development of the enterprise, forms consistent steps of action and, if necessary, requires adjustments to achieve the goals set in the face of market variability. Also, any company has a mission, that is, through it you can understand the meaning and purpose of its existence.

The company's mission is to act as the managing link of the strategy, describe the key characteristics of its work, reflect the tasks of the management level and characterize its main directions, priorities and values. Missions perform their role only if the company has its own goals and objectives. If this is not the case, then the company does not develop, and all its strategies do not play a key role. To determine goals and objectives in management, the SMART system is used ( $\mathrm{S}$ - concreteness, $\mathrm{M}$ - measurability, $\mathrm{A}$ - reach, $\mathrm{R}$ - relevance, $\mathrm{T}$ Time Limitation). Thanks to this system, the company determines what it needs to achieve, how the result of its action will be measured, due to which it will be able to achieve the goal, will be able to understand whether it really needs to complete a particular task to achieve the 
goal, determines the time period in which it will be able to achieve the goal [12].

An important role in the enterprise is played by its financial strategy, which is aimed at improving the financial condition of the company in the distribution of its funds. The HR director is responsible for the financial strategy and its implementation. He, in turn, is responsible for the selection of the company's personnel, determines the work of subordinate departments. Recruitment is important for the company's activities, since the company's employees are carriers of skills, ideas and knowledge.

When drawing up a marketing strategy, the company focuses on studying consumer needs, studying market features, identifying ways to minimize costs and optimize the use of available resources, and using new standards to improve the quality of its products. The R\&D strategy deals with the development and implementation of new technologies or innovations in the production system to increase the level of competitiveness of the company in the market [4].

The development of strategic plans involves the active use of strategic analysis and planning tools. Tools are models, i. e. simplified casts from real processes that describe certain economic patterns that are characteristic of the internal and external business environment. In a generalized form the model for choosing an organization's development strategy and developing ways to implement it is schematically presented in Figure below.

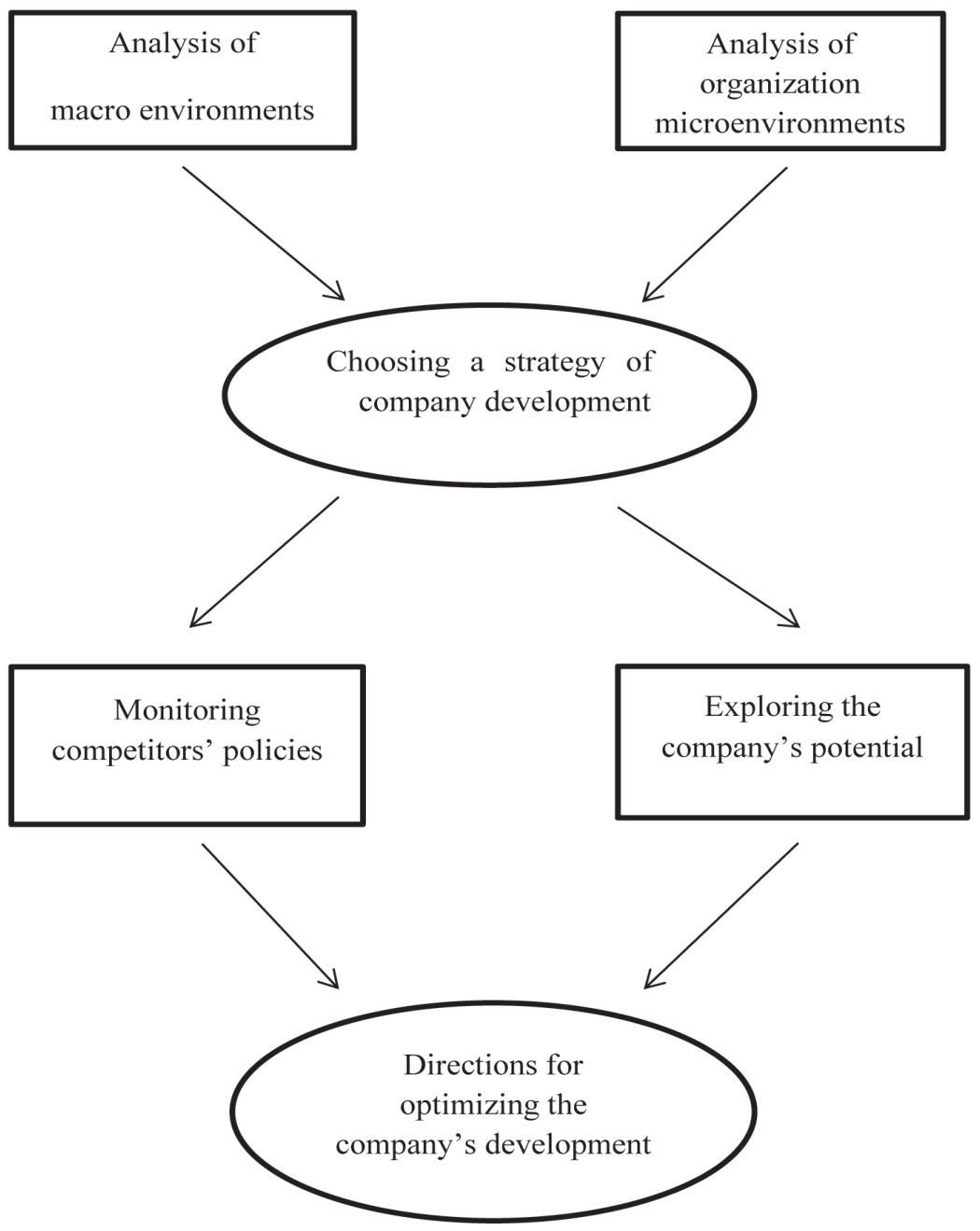

Figure. A model for choosing the company's development strategy and elaborating the ways to implement it

According to this model, the choice of an enterprise development strategy is carried out 
taking into account the analysis of trends characteristic of the micro- and macro-environment of the company. As a result, the application of marketing principles and research tools allows you to analyze the internal and external business environment, assess opportunities and threats that arise in the market.

The choice of the company's strategic course should be supplemented by the development of recommendations for applying alternative marketing approaches to demand management, taking into account the basic concepts of market relations - the formation of needs, demand, and the customer satisfaction mechanism [7].

The development of directions for optimizing the company's development should be carried out taking into account monitoring the actions of competitors. Marketing programs should be analyzed not only by closely located competitors, but also by enterprises operating in a particular sector of the economy as a whole. This is necessary in order to evaluate the possibility of using benchmarking tools.

Benchmarking is the art of identifying the best elements in the work of competitors, studying, improving and applying their working methods and developments in the practice of a particular enterprise. Studying the policies of competitors who are located at a considerable distance from this company is most preferable, because it makes it possible to develop approaches that are not traditional for this market, and does not lead to a direct aggravation of competition [2].

In addition, the development of recommendations aimed at further development of the enterprise should be carried out after a detailed analysis of the potential of the company itself, including the study of financial, material, and labor resources. The possibility of attracting missing resources if necessary should also be considered. A stable position of the enterprise in the market depends not only on a well-developed strategy, but also on the possibility of its successful implementation. In the process of implementing the strategy, force majeure may arise that will cast doubt on the implementation of the planned indicators. The implementation of the strategy means the transformation of the strategic plan into concrete actions, taking into account the market situation of the mechanism of influence of various factors and conditions, which would allow it to significantly reduce errors and miscalculations in determining the further development strategy, thereby ensuring flexibility and maneuverability of the company's activities [8].

Conclusions. Summing up, it should be noted that when developing a strategy, enterprises resort to strategic analysis, determine the sequence of actions and directions of development. The strategy should include such elements as: advantages of the enterprise in relation to competitors, internal development of the enterprise, problems and opportunities of development at the external level, vision of the company's activities in the future, goals and missions of the company, as well as include functional strategies (production, marketing, financial and R\&D strategy).

\section{References}

1. Artemenko L. P., Huk O. V., \& Zhygalkevych Zh. M. (2009). Realizatsiia stratehii rozvytku pidpryiemstva: synerhichnyi pidkhid [Implementation of the Enterprise Development Strategy: a synergistic approach]. Investytsii: praktyka i dosvid-Investment: Practice and Experience, 19, 12-14 [in Ukrainian].

2. Vlasenko V. A. (2014). Rozrobka ta realizatsiia stratehii rozvytku pidpryiemstva v umovakh transformatsii rynkovykh vidnosyn: pryntsypovi pidkhody ta instrumenty [Development and implementation of the enterprise development strategy in the conditions of transformation of market relations: fundamental approaches and tools]. Ekonomika. Menedzhment. Pidpryiemnytstvo - Economy. Management. Entrepreneurship, 26(1), 32-41. Retrieved from http://nbuv.gov.ua/UJRN/ecmepi_2014_26(1)_6 [in Ukrainian].

3. Honcharov Yu. V., \& Lapchyk Yu. Yu. (2014). Udoskonalennia stratehii rozvytku pidpryiemstva [Improving the enterprise development strategy]. Visnyk Kyivskoho natsionalnoho universytetu tekhnolohii ta dyzainu - Bulletin of the Kiev National University of Technology and Design, 1, 193-199. Retrieved from http://nbuv.gov.ua/UJRN/ Vknutd_2014_1_30 [in Ukrainian].

4. Denisiuk I. $(2 \overline{0} 1 \overline{3})$. Stratehiia rozvytku pidpryiemstva kharchovoi promyslovosti: ekonomichna sutnist [Strategy of development of the food industry enterprise: economic 
essence]. Ekonomichnyi analiz - Economic analysis, 12(3), 112-115. Retrieved from http://nbuv.gov.ua/UJRN/ecan_2013_12(3)_25 [in Ukrainian].

5. Zakharchenko R. M. (2014). Süchasni vyklyky shchodo formuvannia ekonomichnoi stratehii rozvytku pidpryiemstva [Modern challenges to the formation of an economic strategy for the development of an enterprise]. Naukovyi visnyk NLTU Ukrainy - Scientific Bulletin of National Forestry University of Ukraine, 24.7, 245-250 [in Ukrainian].

6. Zolotarevsky A. V. (2014). Stvorennia stratehii ekonomichnoho rozvytku pidpryiemstva [Creation of a strategy for economic development of the enterprise]. Formuvannia rynkovykh vidnosyn v Ukraini - Formation of market relations in Ukraine, 11(162), 107-113. Retrieved from http://nbuv.gov.ua/UJRN/frvu_2014_11_23 [in Ukrainian].

7. Klimenko S. M. (2013). Formuvannia stratehii rozvytku pidpryiemstva z urakhuvanniam ryzykiv [Formation of an enterprise development strategy taking into account risks]. Biznes Inform - Business Inform, 8, 343-347 [in Ukrainian].

8. Kobelev V. M., \& Zakharchenko Yu. V. (2013). Teoretychni ta metodolohichni osnovy formuvannia stratehii rozvytku pidpryiemstva [Theoretical and methodological foundations of the formation of the enterprise development strategy]. Visnyk ekonomiky transportu $i$ promyslovosti - Bulletin of Transport and Industrial Economics, 42, 297-303. Retrieved from http://nbuv.gov.ua/UJRN/Vetp_2013_42_41 [in Ukrainian].

9. Kuzmak O. I. (2016). Innovatsiina stratehiia yak zasib stabilizatsii rozvytku promyslovoho pidpryiemstva [Innovative strategy as a means of stabilizing the development of an industrial enterprise]. Innovatsiina ekonomika - Innovative Economy, 1-2, 114-118. Retrieved from http://nbuv.gov.ua/UJRN/inek_2016_1-2_20 [in Ukrainian].

10. Makedon V. V. (2013). Rozrobka stratehii rozvytku promyslovoho pidpryiemstva [Development of a strategy for the development of an industrial enterprise]. Teoretychni $i$ praktychni aspekty ekonomiky ta intelektualnoi vlasnosti - Theoretical and Practical Aspects of Economics and Intellectual Property, 1(1), 369-373. Retrieved from http:// nbuv.gov.ua/UJRN/Tpaeiv_2013_1_1_81 [in Ukrainian].

11. Pogorelov Yu. S. (2017). Sposoby rozvytku pidpryiemstva: umovy ta rezultatyvnist vykorystannia [Methods of enterprise development: conditions and effectiveness of use]. Ekonomichnyi zhurnal Odeskoho politekhnichnoho universytetu - Economic Journal of Odesa Polytechnic University, 1, 76-84. Retrieved from http://nbuv.gov.ua/UJRN/ ejopu_2017_1_15 [in Ukrainian].

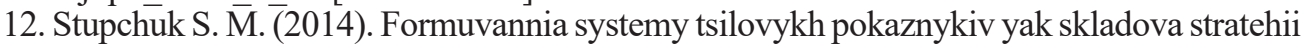
rozvytku pidpryiemstva [Formation of a system of target indicators as a component of the enterprise development strategy]. Visnyk Khmelnytskoho natsionalnoho universytetu. Seriia "Ekonomichni nauky" - Bulletin of Khmelnitsky National University. Series "Economics", vol. 3, issue 3, 168-172 [in Ukrainian].

13. Tur O. V. (2015). Formuvannia poniattia stratehiia rozvytku pidpryiemstva [Formation of the concept of enterprise development strategy]. Intelekt XXI-Intellect XXI, 4, 38-45 [in Ukrainian].

14. Khatser M. V. (2014). Stratehiia rozvytku pidpryiemstva v umovakh nestabilnosti ekonomiky derzhavy [Strategy of enterprise development in conditions of instability of the state economy]. Zbirnyk naukovykh prats Tavriiskoho derzhavnoho ahrotekhnolohichnoho universytetu (ekonomichni nauky) - Collection of Scientific Works of the Tauride State Agrotechnological University (Economics), 3, 109-112. Retrieved from http://nbuv.gov. ua/UJRN/znptdau_2014_3_24 [in Ukrainian].

\section{Bibliographic description for quoting:}

Li Qingsen, Artemenko L. (2021). Aproaches to Forming the Company's Strategic Goals. Scientific Bulletin of National Academy of Statistics, Accounting and Audit-Naukovyy visnyk Natsionalnoi akademiyi statystyky, obliku ta audytu, 1-2, 29-35. doi:10.31767/ nasoa.1-2-2021.04. 